\title{
Analisis Pemasaran Wisata Kuliner Terhadap Peningkatan Pendapatan Masyarakat di Kabupaten Kerinci
}

\author{
Gampo Haryono, Edia Satria, Ayu Esteka Sari \\ STIE Sakti Alam Kerinci \\ Correspondence email: gampo.haryono@yahoo.co.id \\ Email: ediasatria@yahoo.co.id \\ Email: ayuesteka82@gmail.com
}

\begin{abstract}
The importance of a tourist destination in promoting cultural heritage and indeed its contribution to the tourism industry as a whole. Diversity in culture must be seen as a strength in the marketing of food tourism. The impact of culinary tourism is huge and can improve the overall economy of any country. Tourists are more inclined to continue to demand more traditional food because this allows access to cultural and historical heritage of various cultures to make it more authentic. Culinary arts is one of the attractions for tourists who are traveling with the aim of enjoying various types of food typical of places that are headed. Culinary tourism is part of agribusiness that focuses specifically on searching for, and enjoying, preparing food and drinks. Several goals have taken the concept of sustainability to a new level and have begun to offer food and beverage oriented. The research method used in this research is descriptive method with data processing in this study carried out qualitatively and quantitatively, with Analytical Hierarchy Process (AHP) analysis. Analytical Hierarchy Process (AHP) is used as a tool to determine which strategies should be prioritized by the Kerinci Regency to support the marketing activities of Culinary Tourism.
\end{abstract}

Keyword: tourist destination, Analytical Hierarchy Process

\section{Pendahuluan}

Sektor parawisata merupakan salah satu sektor strategis yang harus dimanfaatkan untuk pembangunan keparawisataan sebagai bagian dari pembangunan Nasional, mempunyai tujuan antara lain memperluas kesempatan berusaha dan membuka lapangan kerja. Sejalan dengan tahap-tahap pembangunan nasional. Pelaksanaan pembangunan keparawisataan Nasional dilaksanakan secara menyeluruh. Pembangunan dibidang keparawisataan mempunyai tujuan akhir untuk meningkatkan pendapatan masyarakat yang pada akhirnya dapat meningkatkan kesejahteraan masyarakat.Seni kuliner menjadi salah satu daya tarik bagi wisatawan yang sedang mengadakan perjalanan dengan tujuan untuk menikmati berbagai jenis makanan khas tempat yang dituju. Wisata kuliner adalah bagian dari agribisnis yang berfokus khusus pada pencarian, dan kenikmatan, menyiapkan makanan dan minuman. Pariwisata kuliner didefinisikan sebagai keinginan untuk menikmati jenis makanan tertentu atau hasil dari wilayah tertentu dan mencakup sejumlah besar peluang gastronomi bagi wisatawan (Okech, 2014) serta melibatkan berbagai skema pengembangan ekonomi.Jadi dapat disimpulkan bahwa wisata kuliner ialah perjalanan yang memanfaatkan masakan serta suasana lingkungannya sebagai objek tujuan Wisata.

Sebuah survei mengenai perilaku para wisatawan mengungkapkan bahwa bagi lebih dari sepertiga wisatawan di Asia Pasifik, makanan dan minuman adalah faktor penentu dalam memilih tujuan wisata mereka (Rahayu, 2014). Oleh karena itu, untuk mendukung daya tarik wisata perlu jasa penyediaan makanan dan minuman (food and beverage service) yang baik, seperti restoran, rumah makan dan toko (Ansofino, 2012).Kabupaten Kerinci sejatinya menyimpan kekayaan kuliner yang melimpah. Akan tetapi kuliner-kuliner tersebut belum dikemas sedemikian rupa untuk menarik minat wisatawan. Keragaman kuliner itu tidak lepas dari kekayaan alam dan budaya yang sangat berperan dalam menciptakan makananmakanan khas Kabupaten Kerinci. Seperti Dendeng Batokok merupakan salah satu ikon kuliner khas Kerinci yang banyak dicari. Dendeng Batokok disajikan bersama beras payo, Beras Payo merupakan beras endemik Kerinci, Kantung Semar atau Nephents Ampularia merupakan salah satu flora yang mudah dijumpai di Taman Nasional Kerinci Seblat. Masyarakat Kerinci mengolah Kantung Semar menjadi Lemang Kantong Semar atau biasa disebut dengan kancung beruk. Air Sebuk Kawo ini terbuat dari tunas muda pohon kopi yang dikeringkan. Setelah kering, daun tunas muda pohon kopi kemudian diremas dan diseduh dengan air panas. Air seduhan tunas muda pohon kopi ini kemudian diminum. Biasanya, air kawo disajikan dalam tempurung kelapa. Dodol Kentang Kerinci, berbahan dasar kentang granola, dodol Kerinci punya cita 
rasa manis dengan tekstur yang lebih lembut dan tidak lengket. dengan berbagai varian rasa seperti durian, gula aren, nanas dan pandan. Pentingnya sebuah destinasi wisata dalam mempromosikan warisan budaya dan memang kontribusinya terhadap industri pariwisata secara keseluruhan. Keragaman dalam budaya harus dilihat sebagai kekuatan dalam pemasaran pariwisata makanan. Dampak pariwisata makanan sangat besar dan dapat meningkatkan ekonomi keseluruhan negara mana pun. Wisatawan lebih cenderung untuk terus menuntut makanan yang lebih tradisional karena ini memungkinkan akses ke warisan budaya dan sejarah dari berbagai budaya untuk membuatnya lebih otentik. Beberapa tujuan telah membawa konsep keberlanjutan ke tingkat yang baru dan telah mulai menawarkan makanan dan minuman yang berorientasi. Akibatnya, makanan dan minuman menjadi lebih penting dan memiliki prioritas lebih tinggi. Identitas kuliner dan warisan dapat diperluas dan dieksploitasi dalam pengembangan kerangka pariwisata warisan budaya karena jelas bahwa makanan merupakan elemen penting dalam pembangunan (Okech, 2014). Wisata kuliner menjadi sebuah gaya hidup baru dari masyarakat secara tidak sadar, dimana kebiasaan makan tidak hanya menjadi kebutuhan primer, tetapi juga menjadi kebutuhan tersier (Eko dalam Prayogi, 2017).

Kuliner adalah suatu kegiatan hidup yang erat kaitannya dengan konsumsi makanan sehari-hari dan kuliner merupakan sebuah gaya hidup yang tidak dapat dipisahkan dari kehidupan sehari-hari, di mana kuliner dapat mengembangkan perekonomian daerah sesuai makanan khas daerah yang dapat menciptakan lapangan kerja dan mengentaskan kemiskinan melalui kegiatan wisata kuliner. Oleh karena itu, kuliner perlu dimasukkan ke dalam sektor pengembangan ekonomi kreatif (Rismiyanto, 2015). Torres (2002), menyatakan pariwisata kuliner sebagai jaring yang tersusun secara spasial yang berhubungan dan sumber daya yang diperlukan untuk mengintegrasikan produk makanan dan budaya pertanian sebagai komoditas tunggal dan membawa komoditas ini ke pasar lokal untuk dikonsumsi oleh wisatawan. Beberapa aktor utama dalam jaringan ini termasuk pertanian kecil, pengolah makanan, koperasi pertanian, pasar petani, pertanian yang didukung masyarakat, toko kelontong koperasi, restoran lokal, dan toko makanan khusus. Richardson (2010), menyatakan dampak wisata kuliner terhadap pendapatan masyarakat: (1) peningkatan kesempatan berusaha, dengan adanya wisata kuliner akan menjadi peluang bagi masyarakat yang hendak membuka tempat lokasi baru yang menyediakan beragam kebutuhan wisatawan khususnya wisata kuliner, seperti calon pengusaha akan membuka restaurant yang menyediakan jenis makanan dan minuman tradisional; (2) peningkatan kesempatan kerja, hal ini akan menjadi peluang bagi masyarakat yang akan bekerja di bidang wisata kuliner. seperti koki atau juru masak yang dibutuhkan untuk memasak makanan khas daerah tertentu; (3) peningkatan penerimaan pajak, hal ini mungkin berkaitan dengan perizinan untuk bisnis kuliner restaurant atau yang dinamakan Tanda Daftar Usaha Pariwisata (TDUP); (4) peningkatan nilai tambah produk hasil kebudayaan, hal ini akan menguntungkan masyarakat yang bekerja di bidang wisata kuliner khususnya makanan daerah jika menjual suatu makanan khas yang banyak disukai wisatawan; dan (5) peningkatan harga, dengan meningkatnya kebutuhan bahan dasar makanan otomatis akan mengalami kenaikan hargajual.

\section{METODE}

Metode penelitian yang digunakan dalam penelitian ini adalah metode deskriptif dengan Pengolahan data pada penelitian ini dilakukan secara kualitatif dan kuantitatif AHP (analitycal Hierarchy Process) akan digunakan dan berfungsi sebagai alat untuk menentukan strategi mana yang harus diprioritaskan oleh Kabupaten Kerinci untuk menunjang kegiatan pemasaran Wisata Kuliner. Responden dalam penelitian ini adalah pelaku bisnis makanan tradisional yang berada di Kabupaten Kerinci. Melalui beberapa pertanyaan yang telah disediakan berkenaan dengan pelaksanaan peningkatan kualitas WisataKuliner di Kabupaten Kerinci

\section{Metode Analytical Hierarchy Process (AHP)}

Kerangka kerja AHP terdiri dari delapan langkah utama,delapan langkah tersebut adalah:

1. Mendefinisikan persoalan dan merinci pemecahan persoalan yang diinginkan, pemilihan tujuan, kriteria dan elemen-elemen yang menyusun struktur hirarki;

2. Membuat struktur hirarki. Hirarki merupakan abstraksi struktur suatu sistem yang mempelajari fungsi interaksi antar komponen dan dampaknya terhadap sistem. Abstraksi ini membuat bentuk yang berkaitan, tersusun dari sasaran utama, kriteria dalam mencapai sasaran utama, sub-sub dari kriteria dan 
yang terakhir adalah alternatif strategi;

3. Menyusun matriks berbanding berpasangan. Matriks ini di mulai dari puncak hirarki, yang merupakan dasar untuk melakukan perbandingan berpasangan antar elemen yang terkait yang ada dibawahnya. Perbandingan berpasangan pertama dilakukan dalam elemen tingkat kedua terhadap fokus yang ada dipunca khirarki.

4. Mensistensis prioritas untuk melakukan pembobotan vektor vektor prioritas.

5. Mengevaluasi Inkonsistensi

\section{HASIL}

\section{Matriks perbandingan berpasangan (pairwaise comparison)}

Setelah hirarki dari Analytical Hierarchy Process (AHP) terbentuk, kemudian menyusun Matriks perbandingan berpasangan (pairwaise comparison) dan bertujuan untuk mencari bobot dari masing masing hirarki. Matriks perbandingan berpasangan (pairwaise comparison) pada penelitian ini adalah :

1) Analisis Unsur Pada Level Kedua

Analisis Unsur Faktor Pada Level Kedua memiliki tujuan untuk melihat tingkat pengaruh unsur faktor pada level kedua terhadap sasaran utamanya yaitu analisis Strategi Pengembangan Wisata Kuliner di Kabupaten Kerinci. Berikut merupakan tabel Bobot dan prioritas :

Tabel 1

Matriks perbandingan berpasangan Unsur Faktor Pada Level Kedua

\begin{tabular}{|c|c|c|c|c|c|c|c|c|c|c|c|c|}
\hline Kriteria & $\begin{array}{l}\text { Anggaran } \\
\text { Promosi }\end{array}$ & $\begin{array}{l}\text { Keunikan } \\
\text { Produk }\end{array}$ & $\begin{array}{c}\text { Harga Yang } \\
\text { Bersaing }\end{array}$ & $\begin{array}{c}\text { Kemudahan } \\
\text { Mendapatkan } \\
\text { Produk }\end{array}$ & $\begin{array}{l}\text { Value } \\
\text { Eigen }\end{array}$ & $\begin{array}{l}\text { Value } \\
\text { Prionity }\end{array}$ & $\begin{array}{c}\text { Anggaran } \\
\text { Promosi }\end{array}$ & $\begin{array}{c}\text { Keunikan } \\
\text { Produk }\end{array}$ & \begin{tabular}{|c|} 
Harga Yang \\
Bersaing
\end{tabular} & $\begin{array}{c}\text { Kemudahan } \\
\text { Mendapatkan } \\
\text { Produk }\end{array}$ & $\begin{array}{c}\text { Value } \\
\text { Altemative }\end{array}$ & Lamda \\
\hline Anggaran Promosi & 1,0000 & 0,5774 & 0,9193 & 0,2049 & 0,5743 & 0,1347 & 0,1149 & 0,1170 & 0,3060 & 0,0541 & 0,5920 & $4,395 \mathrm{~s}$ \\
\hline $\begin{array}{l}\text { Keunikan Produk } \\
\text { Harga Y ang }\end{array}$ & 1,7321 & 1,0000 & 0,5774 & 0,6148 & 0,885 & 0,2076 & 0,1991 & 0,2026 & 0,1921 & 0,1623 & 0,7561 & $3,641 \mathrm{C}$ \\
\hline Bersaing & 1,0878 & 1,7321 & 1,0000 & 1,9680 & $1,387 \mathrm{~d}$ & 0,3254 & $0,125 \mathrm{~d}$ & $0,350 \mathrm{~g}$ & 0,3328 & 0,5196 & 1,3283 & $4,082 \%$ \\
\hline $\begin{array}{l}\text { Kemudahan } \\
\text { Mendapatkan } \\
\text { Produk }\end{array}$ & 4,8797 & 1,6266 & 0,5081 & $1,000 \mathrm{~d}$ & 1,4171 & 0,3323 & 0,5609 & 0,329 & 0,1691 & 0,2640 & $1,323 \mathrm{~d}$ & $3,983 \mathrm{C}$ \\
\hline Jumlah Total & 8,6995 & 4,9360 & 3,0048 & 3,7877 & $4,264 \mathrm{C}$ & 1,0000 & & & \multicolumn{3}{|c|}{$\begin{array}{l}\text { Rataan } \\
\text { CI (Consistency Index) } \\
\text { IR (Index Ratio) }\end{array}$} & $\begin{array}{r}16,102 ; \\
4,025 i \\
0,008 \mathrm{C} \\
0,0951 \\
\end{array}$ \\
\hline
\end{tabular}

Sumber: data olahan

Hasil perhitungan pada tabel di atas maka hasil menunjukkan nilai CI (Consistency Index) CI< 0.1, maka konsistensi dari hasil pembobotan dapat diterima

2) Analisis Unsur Pada Level Ketiga

Analisis Unsur Faktor Pada Level Ketiga memiliki tujuan untuk melihat tingkat pengaruh unsur faktor pada strategi pengembangan wisata kuliner terhadap dampak yang diberikan kepada masyarakat di Kabupaten Kerinci. Berikut merupakan tabel Bobot dan prioritas :

Tabel 2

Matriks perbandingan berpasangan Anggaran Promosi

\begin{tabular}{|c|c|c|c|c|c|c|c|c|c|c|c|c|c|c|}
\hline $\begin{array}{l}\text { Anggaran } \\
\text { Promosi }\end{array}$ & PKB & PKK & PPP & PNT & $\mathrm{PH}$ & $\begin{array}{l}\text { Value } \\
\text { Eigen }\end{array}$ & \begin{tabular}{|c|} 
Value \\
Pri ority
\end{tabular} & PKB & PKK & PPP & PNT & $\mathrm{PH}$ & \begin{tabular}{|c|} 
Value \\
Alternative
\end{tabular} & Lamda \\
\hline PKB & 1,0000 & 0,4671 & 0,8801 & 0,5081 & 0,4472 & 0,6224 & 0,1095 & 0,1179 & 0,0413 & 0,0793 & 0,1151 & 0,1517 & 0,5053 & 4,6156 \\
\hline PKK & 2,1407 & 1,0000 & 0,2229 & 0,2374 & 0,8801 & 0,6306 & 0,1109 & 0,2524 & 0,0885 & 0,0201 & 0,0538 & 0,2986 & 0,7133 & 6,4315 \\
\hline PPP & 1,1362 & 4,4860 & 1,0000 & 0,2374 & 0,2089 & 0,7595 & 0,1336 & 0,1340 & 0,3969 & 0,0901 & 0,0538 & 0,0709 & 0,7456 & 5,5809 \\
\hline PNT & 1,9680 & 4,2129 & 4,2129 & 1,0000 & 0,4111 & 1,7039 & 0,2997 & 0,2320 & 0,3727 & 0,3794 & 0,2265 & 0,1395 & 1,3502 & 4,5052 \\
\hline $\mathrm{PH}$ & 2,2361 & 1,1362 & 4,7867 & 2,4323 & 1,0000 & 1,9688 & 0,3463 & 0,2637 & 0,1005 & 0,4311 & 0,5509 & 0,3393 & 1,6855 & 4,8671 \\
\hline Jumlah Total & 8,4810 & 11,3023 & 11,1026 & 4,4152 & 2,9474 & 5,6852 & 1,0000 & & & & \multicolumn{3}{|c|}{ Jumlah Total } & 26,0004 \\
\hline & & & & & & & & & & & \multicolumn{3}{|l|}{ Rataan } & 5,2001 \\
\hline & & & & & & & & & & & \multirow{2}{*}{\multicolumn{3}{|c|}{$\begin{array}{l}\mathrm{CI} \text { (Consistency Index) } \\
\text { IR (Index Ratio) }\end{array}$}} & 0,0500 \\
\hline & & & & & & & & & & & & & & 0,0447 \\
\hline
\end{tabular}

Sumber: data olahan 
Gampo Haryono et al, Analisis Pemasaran Wisata Kuliner Terhadap Peningkatan Pendapatan Masyarakat di Kabupaten Kerinci

Hasil perhitungan pada tabel di atas maka hasil menunjukkan nilai CI (Consistency Index) CI< 0.1 , maka konsistensi dari hasil pembobotan dapat diterima

Tabel 3

\begin{tabular}{|c|c|c|c|c|c|c|c|c|c|c|c|c|c|c|}
\hline \multirow{3}{*}{$\begin{array}{l}\text { Keunikan } \\
\text { Produk } \\
\text { PKB }\end{array}$} & \multicolumn{14}{|c|}{ Matriks perbandingan berpasangan Keunikan Produk } \\
\hline & PKB & PKK & PPP & PNT & $\mathrm{PH}$ & $\begin{array}{l}\text { Value } \\
\text { Eigen }\end{array}$ & $\begin{array}{l}\text { Value } \\
\text { Priority }\end{array}$ & $\mathrm{PKB}$ & PKK & PPP & PNT & $\mathrm{PH}$ & $\begin{array}{l}\text { Value } \\
\text { Alternative }\end{array}$ & Lamda \\
\hline & 1,0000 & 0,4671 & 2,1407 & 0,2934 & 0,5081 & 0,6834 & 0,1371 & 0,1113 & 0,0612 & 0,3830 & 0,0362 & 0,1671 & 0,7587 & 5,5353 \\
\hline PKK & 2,1407 & 1,0000 & 0,2697 & 4,4006 & 0,4472 & 1,0259 & 0,2058 & 0,2383 & 0,1309 & 0,0483 & 0,5427 & 0,1471 & 1,1072 & 5,3810 \\
\hline PPP & 0,4671 & 3,7078 & 1,0000 & 0,4472 & 0,5774 & 0,8513 & 0,1707 & 0,0520 & 0,4854 & 0,1789 & 0,0551 & 0,1899 & 0,9613 & 5,6301 \\
\hline PNT & 3,4087 & 0,2272 & 0,4472 & 1,0000 & 0,5081 & 0,7065 & 0,1417 & 0,3794 & 0,0298 & 0,0800 & 0,1233 & 0,1671 & 0,7796 & 5,5016 \\
\hline $\mathrm{PH}$ & 1,9680 & 2,2361 & 1,7321 & 1,9680 & 1,0000 & 1,7188 & 0,3447 & 0,2190 & 0,2927 & 0,3099 & 0,2427 & 0,3289 & 1,3932 & 4,0415 \\
\hline \multirow[t]{4}{*}{ Jumlah } & 8,9845 & 7,6382 & 5,5897 & 8,1091 & 3,0408 & 4,9859 & 1,0000 & \multicolumn{6}{|c|}{ Jumlah Total } & 26,0895 \\
\hline & & & & & & & & & & & \multicolumn{3}{|l|}{ Rataan } & 5,2179 \\
\hline & & & & & & & & & & & \multicolumn{3}{|c|}{ CI (Consistency Index) } & 0,0545 \\
\hline & & & & & & & & & & & \multicolumn{3}{|c|}{ IR (Index Ratio) } & 0,0486 \\
\hline
\end{tabular}

Sumber: data olahan

Hasil perhitungan pada tabel di atas maka hasil menunjukkan nilai CI (Consistency Index) CI $<0.1$, maka konsistensi dari hasil pembobotan dapat diterima

Tabel 4

Matriks perbandingan berpasangan Harga Yang Bersaing

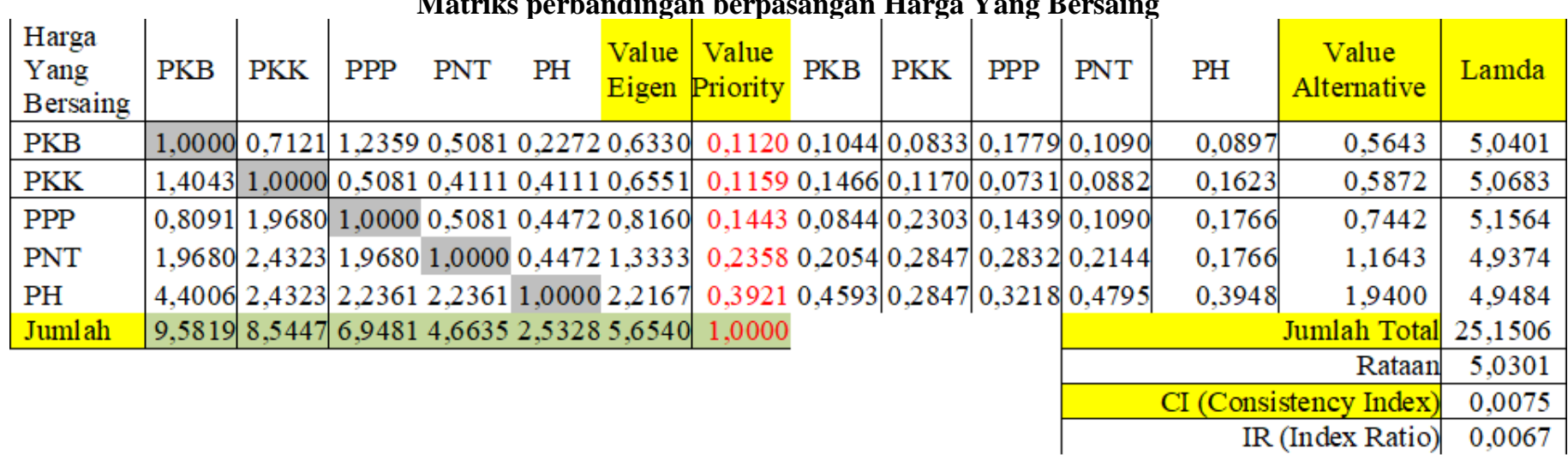

Sumber: data olahan

Hasil perhitungan pada tabel di atas maka hasil menunjukkan nilai CI (Consistency Index) $\mathrm{CI}<0.1$, maka konsistensi dari hasil pembobotan dapat diterima

Tabel 5

\begin{tabular}{|c|c|c|c|c|c|c|c|c|c|c|c|c|c|c|}
\hline \multicolumn{15}{|c|}{ Matriks perbandingan berpasangan Kemudahan Mendapatkan Produk } \\
\hline $\begin{array}{l}\text { Kemudahan } \\
\text { Mendapatkan } \\
\text { Produk }\end{array}$ & PKB & PKK & PPP & PNT & $\mathrm{PH}$ & $\begin{array}{l}\text { Value } \\
\text { Eigen }\end{array}$ & $\begin{array}{l}\text { Value } \\
\text { Priority }\end{array}$ & PKB & PKK & PPP & PNT & $\mathrm{PH}$ & $\begin{array}{l}\text { Value } \\
\text { Alternative }\end{array}$ & Lamda \\
\hline PKB & 1,0000 & 1,1362 & 0,9573 & 1,9680 & 0,8801 & 1,1351 & 0,2202 & 0,2189 & 0,2157 & 0,2144 & 0,2667 & 0,1602 & 1,0758 & 4,8862 \\
\hline PKK & 0,8801 & 1,0000 & 0,5081 & 1,9680 & 1,5244 & 1,0605 & 0,2057 & 0,1926 & 0,1898 & 0,1138 & 0,2667 & 0,2776 & 1,0405 & 5,0575 \\
\hline PPP & 1,0446 & 1,9680 & 1,0000 & 1,5244 & 1,0000 & 1,2566 & 0,2438 & 0,2286 & 0,3736 & 0,2239 & 0,2066 & 0,1821 & 1,2147 & 4,9833 \\
\hline PNT & 0,5081 & 0,5081 & 1,0000 & 1,0000 & 1,0878 & 0,7757 & 0,1505 & 0,1112 & 0,0965 & 0,2239 & 0,1355 & 0,1981 & 0,7652 & 5,0851 \\
\hline $\mathrm{PH}$ & 1,1362 & 0,6560 & 1,0000 & 0,9193 & 1,0000 & 0,9272 & 0,1799 & \multirow[t]{5}{*}{0,2487} & \multirow[t]{5}{*}{$|0,1245|$} & \multirow[t]{5}{*}{0,2239} & & 0,1821 & 0,9038 & 5,0250 \\
\hline Jumlah & 4,5690 & 5,2683 & 4,4655 & 7,3797 & 5,4923 & 5,1551 & 1,0000 & & & & \multicolumn{3}{|c|}{$\begin{array}{l}0,1240 \\
\text { Jumlah Total }\end{array}$} & 25,0371 \\
\hline & & & & & & & & & & & \multicolumn{3}{|l|}{ Rataan } & 5,0074 \\
\hline & & & & & & & & & & & \multirow{2}{*}{\multicolumn{3}{|c|}{ CI (Consistency Index) }} & 0,0019 \\
\hline & & & & & & & & & & & & & & 0,0017 \\
\hline
\end{tabular}

Sumber: data diolah

Hasil perhitungan pada tabel di atas maka hasil menunjukkan nilai CI (Consistency Index) $\mathrm{CI}<0.1$, maka konsistensi dari hasil pembobotan dapat diterima

3) Analisis Unsur Pada Level Ketiga 
Gampo Haryono et al, Analisis Pemasaran Wisata Kuliner Terhadap Peningkatan Pendapatan Masyarakat di Kabupaten Kerinci

Analisis Unsur Faktor Pada Level Ketiga memiliki tujuan untuk melihat tingkat pengaruh unsur faktor pada level Ketiga terhadap alternative dari Strategi Pengembangan Wisata Kuliner di Kabupaten Kerinci. Berikut merupakan tabel Bobot dan prioritas :

Tabel 6

\begin{tabular}{|c|c|c|c|c|c|c|c|c|c|c|c|c|}
\hline \multicolumn{13}{|c|}{ Matriks perbandingan berpasangan Peningkatan Kesempatan Berusaha (PKB) } \\
\hline PKB & A & B & $\mathrm{C}$ & D & $\begin{array}{l}\text { Value } \\
\text { Eigen }\end{array}$ & $\begin{array}{l}\text { Value } \\
\text { Priority }\end{array}$ & A & B & $\mathrm{C}$ & D & $\begin{array}{l}\text { Value } \\
\text { Alternative }\end{array}$ & Lamda \\
\hline A & 1,0000 & 2,1407 & 0,5774 & 0,5081 & 0,8902 & 0,1938 & 0,1935 & 0,2869 & 0,0768 & 0,2496 & 0,8068 & 4,1622 \\
\hline B & 0,4671 & 1,0000 & 2,2361 & 0,2582 & 0,7206 & 0,1569 & 0,0904 & 0,1340 & 0,2973 & 0,1268 & 0,6486 & 4,1332 \\
\hline $\mathrm{C}$ & 1,7321 & 0,4472 & 1,0000 & 0,2697 & 0,6761 & 0,1472 & 0,3352 & 0,0599 & 0,1330 & 0,1325 & 0,6606 & 4,4873 \\
\hline D & 1,9680 & 3,8730 & 3,7078 & 1,0000 & 2,3057 & 0,5020 & \multirow[t]{5}{*}{0,3809} & \multirow[t]{5}{*}{0,5191} & 0,4930 & 0,4912 & 1,8841 & 3,7529 \\
\hline Jumlah Total & 5,1672 & 7,4609 & 7,5212 & 2,0360 & 4,5926 & 1,0000 & & & \multicolumn{3}{|c|}{ Jumlah Total } & 16,5355 \\
\hline & & & & & & & & & \multicolumn{3}{|l|}{ Rataan } & 4,1339 \\
\hline & & & & & & & & & \multirow{2}{*}{\multicolumn{3}{|c|}{ CI (Consistency Index) }} & 0,0446 \\
\hline & & & & & & & & & & & & 0,4958 \\
\hline
\end{tabular}

Sumber: data olahan

Hasil perhitungan pada tabel di atas maka hasil menunjukkan nilai CI (Consistency Index) CI< 0.1, maka konsistensi dari hasil pembobotan dapat diterima

Tabel 7

\begin{tabular}{|c|c|c|c|c|c|c|c|c|c|c|c|c|}
\hline \multicolumn{13}{|c|}{ Matriks perbandingan berpasangan Peningkatan Kesempatan Kerja (PKK) } \\
\hline PKK & A & B & $\mathrm{C}$ & $\mathrm{D}$ & $\begin{array}{l}\text { Value } \\
\text { Eigen }\end{array}$ & $\begin{array}{l}\text { Value } \\
\text { Priority }\end{array}$ & A & B & $\mathrm{C}$ & D & $\begin{array}{l}\text { Value } \\
\text { Alternative }\end{array}$ & Lamda \\
\hline A & 1,0000 & 0,5081 & 1,0000 & 1,7321 & 0,9686 & 0,2342 & 0,2200 & 0,1261 & 0,1248 & 0,3939 & 0,8648 & 3,6929 \\
\hline B & 1,9680 & 1,0000 & 5,2068 & 0,4295 & 1,4484 & 0,3502 & 0,4330 & 0,2482 & 0,6496 & 0,0977 & 1,4284 & 4,0792 \\
\hline $\mathrm{C}$ & 1,0000 & 0,1921 & 1,0000 & 1,2359 & 0,6980 & 0,1688 & 0,2200 & 0,0477 & 0,1248 & 0,2811 & 0,6735 & 3,9909 \\
\hline $\mathrm{D}$ & 0,5774 & 2,3286 & 0,8091 & 1,0000 & 1,0213 & 0,2469 & \multirow[t]{5}{*}{0,1270} & \multirow[t]{5}{*}{0,5780} & 0,1009 & 0,2274 & 1,0333 & 4,1852 \\
\hline Jumlah Total & 4,5453 & 4,0287 & 8,0159 & 4,3974 & 4,1362 & 1,0000 & & & \multicolumn{3}{|c|}{ Jumlah Total } & 15,9482 \\
\hline & & & & & & & & & \multicolumn{3}{|l|}{ Rataan } & 3,9870 \\
\hline & & & & & & & & & \multirow{2}{*}{\multicolumn{3}{|c|}{ CI (Consistency Index) }} & $-0,0043$ \\
\hline & & & & & & & & & & & & $-0,0480$ \\
\hline
\end{tabular}

Sumber: data olahan

Hasil perhitungan pada tabel di atas maka hasil menunjukkan nilai CI (Consistency Index) $\mathrm{CI}<0.1$, maka konsistensi dari hasil pembobotan dapat diterima

Tabel 8

\begin{tabular}{|c|c|c|c|c|c|c|c|c|c|c|c|c|}
\hline \multicolumn{13}{|c|}{ Matriks perbandingan berpasangan Peningkatan Penerimaan Pajak (PPP) } \\
\hline PPP & A & B & $\mathrm{C}$ & D & $\begin{array}{l}\text { Value } \\
\text { Eigen }\end{array}$ & $\begin{array}{l}\text { Value } \\
\text { Priority }\end{array}$ & A & B & $\mathrm{C}$ & D & $\begin{array}{l}\text { Value } \\
\text { Alternative }\end{array}$ & Lamda \\
\hline A & 1,0000 & 0,8091 & 2,4323 & 0,5774 & 1,0324 & 0,2405 & 0,2284 & 0,2730 & 0,2837 & 0,1603 & 0,9453 & 3,9303 \\
\hline B & 1,2359 & 1,0000 & 1,7321 & 1,7321 & 1,3876 & 0,3233 & 0,2822 & 0,3374 & 0,2020 & 0,4808 & 1,3024 & 4,0289 \\
\hline $\mathrm{C}$ & 0,4111 & 0,5774 & 1,0000 & 0,2934 & 0,5137 & 0,1197 & 0,0939 & 0,1948 & 0,1166 & 0,0814 & 0,4868 & 4,0674 \\
\hline $\mathrm{D}$ & 1,7321 & 0,5774 & 3,4087 & 1,0000 & 1,3588 & 0,3165 & \multirow[t]{5}{*}{0,3955} & 0,1948 & 0,3976 & 0,2776 & 1,2655 & 3,9979 \\
\hline Jumlah Total & 4,3791 & 2,9638 & 8,5730 & 3,6028 & 4,2926 & 1,0000 & & & \multicolumn{3}{|c|}{ Jumlah Total } & 16,0246 \\
\hline & & & & & & & & & \multicolumn{3}{|l|}{ Rataan } & 4,0061 \\
\hline & & & & & & & & & \multicolumn{3}{|c|}{ CI (Consistency Index) } & 0,0020 \\
\hline & & & & & & & & & \multicolumn{3}{|c|}{ IR (Index Ratio) } & 0,0228 \\
\hline
\end{tabular}

Sumber: data olahan

Hasil perhitungan pada tabel di atas maka hasil menunjukkan nilai CI (Consistency Index) CI< 0.1 , maka konsistensi dari hasil pembobotan dapat diterima

Tabel 9

Matriks perbandingan berpasangan Peningkatan Nilai Tambah Produk (PNT) 
Gampo Haryono et al, Analisis Pemasaran Wisata Kuliner Terhadap Peningkatan Pendapatan Masyarakat di Kabupaten Kerinci

\begin{tabular}{|c|c|c|c|c|c|c|c|c|c|c|c|c|}
\hline PNT & A & B & $\mathrm{C}$ & $\mathrm{D}$ & Value Eigen & Value Priority & A & B & $\mathrm{C}$ & $\mathrm{D}$ & Value Alternative & Lamda \\
\hline A & 1,0000 & 0,3327 & 0,5308 & 1,9680 & 0,7678 & 0,1784 & 0,1563 & 0,0346 & 0,0937 & 0,5699 & 0,8545 & 4,7891 \\
\hline $\mathrm{B}$ & 3,0062 & 1,0000 & 0,2582 & 0,2272 & 0,6481 & 0,1506 & 0,4698 & 0,1041 & 0,0456 & 0,0658 & 0,6853 & 4,5504 \\
\hline $\mathrm{C}$ & 1,8841 & 3,8730 & 1,0000 & 0,2582 & 1,1716 & 0,2723 & 0,2945 & 0,4032 & 0,1766 & 0,0748 & 0,9490 & 3,4855 \\
\hline $\mathrm{D}$ & 0,5081 & 4,4006 & 3,8730 & 1,0000 & 1,7155 & 0,3987 & 0,0794 & 0,4581 & 0,6840 & 0,2896 & 1,5111 & 3,7903 \\
\hline Jumlah Total & 6,3983 & 9,6062 & 5,6620 & 3,4534 & 4,3029 & 1,0000 & & & \multicolumn{3}{|c|}{ Jumlah Total } & 16,6153 \\
\hline & & & & & & & & & \multicolumn{3}{|l|}{ Rataan } & 4,1538 \\
\hline & & & & & & & & & \multicolumn{3}{|c|}{ CI (Consistency Index) } & 0,0513 \\
\hline & & & & & & & & & \multicolumn{3}{|c|}{ IR (Index Ratio) } & 0,5697 \\
\hline
\end{tabular}

Sumber: data olahan

Hasil perhitungan pada tabel di atas maka hasil menunjukkan nilai CI (Consistency Index) $\mathrm{CI}<0.1$, maka konsistensi dari hasil pembobotan dapat diterima

Tabel 10

Matriks perbandingan berpasangan Peningkatan Harga (PH)

\begin{tabular}{|c|c|c|c|c|c|c|c|c|c|c|c|c|}
\hline \\
\hline $\mathrm{PH}$ & A & B & $\mathrm{C}$ & D & Value Eigen & Value Priority & $\mathrm{A}$ & B & $\mathrm{C}$ & D & Value Alternative & Lamda \\
\hline A & 1,0000 & 1,9680 & 2,2361 & 0,8801 & 1,4029 & 0,3261 & 0,3235 & 0,3573 & 0,2972 & 0,3050 & 1,2829 & 3,9346 \\
\hline B & 0,5081 & 1,0000 & 0,8801 & 0,7121 & 0,7512 & 0,1746 & 0,1644 & 0,1815 & 0,1170 & 0,2468 & 0,7096 & 4,0644 \\
\hline $\mathrm{C}$ & 0,4472 & 1,1362 & 1,0000 & 0,2934 & 0,6214 & 0,1444 & 0,1447 & 0,2063 & 0,1329 & 0,1017 & 0,5855 & 4,0541 \\
\hline $\mathrm{D}$ & 1,1362 & 1,4043 & 3,4087 & 1,0000 & 1,5271 & 0,3549 & 0,3675 & 0,2549 & 0,4530 & 0,3465 & 1,4220 & 4,0063 \\
\hline Jumlah Total & 3,0916 & 5,5085 & 7,5248 & 2,8856 & 4,3026 & 1,0000 & & & Jumlah & Total & & 16,0595 \\
\hline & & & & & & & & & Rataan & & & 4,0149 \\
\hline & & & & & & & & & $\mathrm{CI}(\mathrm{Co}$ & isistency & Index) & 0,0050 \\
\hline & & & & & & & & & IR (Ind & x Ratio) & & 0,0551 \\
\hline
\end{tabular}

Sumber: data olahan

Hasil perhitungan pada tabel di atas maka hasil menunjukkan nilai CI (Consistency Index) CI<0.1, maka konsistensi dari hasil pembobotan dapat diterima

\section{Bobot Prioritas Kriteria}

\section{Analisis Unsur Faktor pada Level Kedua}

Setelah didapatkan hasil dari nilai CI (Consistency Index) CI $<0.1$ Maka Pada proses perhitungan selanjutnya dilanjutkan untuk mendapatkan hasil dari bobot prioritas kriteria dan bobot prioritas alternatif terhadap kriteria sehingga dapat dilakukan proses perangkingan.Berikut merupakan tabel Bobot dan prioritas (unsur faktor strategi pengembangan wisata kuliner).

Tabel 11

Bobot Dan Prioritas Strategi Pengembangan Wisata Kuliner

\begin{tabular}{lcr}
\hline \multicolumn{1}{c}{ Unsur Faktor } & Bobot & Prioritas \\
\hline Anggaran Promosi & 0,1347 & 4 \\
Keunikan Produk & 0,2076 & 3 \\
Harga Yang Bersaing & 0,3254 & 2 \\
Kemudahan Mendapatkan Produk & 0,3323 & 1 \\
\hline
\end{tabular}

Sumber: data olahan

Berdasarkan pada pengolahan data pada Tabel 1 dan hasil di Tabel 11, dapat dilihat bahwa prioritas faktor yang memiliki tingkat pengaruh terbesar dalam penyusunan strategi potensi bauran pemasaran pengembangan wisata kuliner adalah Kemudahan Mendapatkan Produk dengan nilai bobot (0,3323). Faktorfaktor berikutnya yang turut berpengaruh dalam strategi potensi bauran pemasaran pengembangan wisata kuliner harga yang bersaing, keunikan produk dan anggaran promosi.Unsur faktor Kemudahan Mendapatkan Produk menjadi prioritas yang paling berpengaruh karena mudahnya mendapatkan produk yang berkaitan dengan pendistribusi dari produk.Dimana produk bisa didapatkan di tokotoko dan tempat tempat penjualan terdekat, sehingga tidak menyulitkan konsumen untuk mendapatkan nya.

\section{Analisis Unsur Tujuan pada Level Ketiga}

Analisis tujuan bertujuan untuk melihat tingkat pengaruh suatu unsur tujuan pada level ketiga terhadap unsur faktor strategi pengembangan wisata kuliner. Berikut merupakan tabel pembobotan unsur 
Gampo Haryono et al, Analisis Pemasaran Wisata Kuliner Terhadap Peningkatan Pendapatan Masyarakat di Kabupaten

tujuan dari pengembangan wisata kuliner yang berdampak terhadap masyarakat Kabupaten Kerinci dan kepada Pembangunan di Kabupaten Kerinci.

Tabel 12

Bobot Dan Prioritas Tujuan Pengembangan Wisata Kuliner

\begin{tabular}{|l|r|r|r|r|r|r|}
\multirow{2}{*}{ Tujuan } & \multicolumn{7}{|c|}{ Faktor } & \multirow{2}{*}{ Bobot } & \multirow{2}{*}{ Prioritas } \\
\cline { 2 - 6 } & Anggaran Promosi & Keunikan Produk & Harga Yang Bersaing & Kemudahan Mendapatkan Produk & \\
\hline PKB & 0,1095 & 0,1371 & 0,1120 & 0,2202 & 0,1528 & 5 \\
PKK & 0,1109 & 0,2058 & 0,1159 & 0,2057 & 0,1637 & 4 \\
\hline PPP & 0,1336 & 0,1707 & 0,1443 & 0,2438 & 0,1814 & 3 \\
\hline PNT & 0,2997 & 0,1417 & 0,2358 & 0,1505 & 0,1965 & 2 \\
\hline PH & 0,3463 & 0,3447 & 0,3921 & 0,1799 & 0,3056 & 1
\end{tabular}

Sumber: data olahan

Berdasarkan pada pengolahan data pada tabel 2 sampai tabel 5 dan hasil di tabel 12, dapat dilihat bahwa prioritas tujuan yang memiliki tingkat pengaruh terbesar dalam strategi potensi pengembangan wisata kuliner adalah Peningkatan Harga dengan nilai bobot (0,3056). Faktor-faktor berikutnya yang turut berpengaruh dalam tujuan pengembangan wisata kuliner Peningkatan Nilai Tambah Produk, Peningkatan Penerimaan Pajak, Peningkatan Kesempatan Kerja dan Peningkatan Kesempatan Beusaha. Peningkatan Harga dari produk produk wisata kuliner menjadi salah satu tujuan dari pengembangan strategi wisata kuliner, dengan harga yang meningkat hal ini akan berdampak terhadap peningkatan pendapatan dan kesejahteraan dari masyarakat yang bergerak dalam usaha kuliner ini. Selain itu harga juga berfungsi dalam membantu para pembeli untuk memutuskan cara memperoleh manfaat yang diharapkan berdasarkan daya belinya.

\section{Analisis Unsur Alternatif pada Level Keempat}

Analisis alternatif yang bertujuan untuk melihat tingkat pengaruh suatu unsur alternatif pada level keempat terhadap tujuan-tujuan yang terdapat pada level ketiga. Berikut merupakan tabel pembobotan unsur alternative dari pengembanagan wisata kuliner yang berdampak terhadap kepada masyaraat Kabupaten Kerinci dan kepada Pembangunan di Kabupaten Kerinci.

Tabel 13

Bobot Dan Prioritas Alternatif Pengembangan Wisata Kuliner

\begin{tabular}{llllllll}
\hline & Tujuan & & & & \multirow{2}{*}{ Bobot } & Prioritas \\
Alternatif & PKB & PKK & PPP & PNT & PH & 0,2463 & 2 \\
A & 0,1938 & 0,2342 & 0,2405 & 0,1784 & 0,3261 & 0,2229 & 3 \\
B & 0,1569 & 0,3502 & 0,3233 & 0,1506 & 0,1746 & 0,1695 & 4 \\
C & 0,1472 & 0,1688 & 0,1197 & 0,2723 & 0,1444 & 0,3614 & 1 \\
\hline
\end{tabular}

Sumber: data olahan

Berdasarkan pada pengolahan data pada tabel 6 sampai tabel 9 dan hasil di tabel 13, dapat dilihat bahwa prioritas alternative yang memiliki tingkat pengaruh terbesar dalam strategi potensi pengembangan wisata kuliner adalah Meningkatkan Keunikan Cita Rasa, Aroma dan Penyajian dengan nilai bobot (0,3614). Faktor-faktor berikutnya yang turut berpengaruh dalam tujuan pengembangan wisata kuliner adalah Menerapkan Promosi Penjualan, Mendukung Kegiatan Pelestarian Kuliner dan Meningkatkan Kualitas Makanan Tradisional.Meningkatkan Keunikan Cita Rasa, Aroma dan Penyajian dari produk produk wisata kuliner menjadi alternative strategi terbaik dari pengembangan strategi wisata kuliner di Kabupaten Kerinci.Dengan adanya keunikan dari Rasa atau aroma yang dimiliki oleh masing-masing masakan sangat khas.Kekhasan yang dimiliki adalah yang hanya bisa ditemukan di Kerinci. Sehingga memilliki keunikan tersendiri .sepertiKantung Semar atau Nephents Ampularia merupakan salah satu flora yang mudah dijumpai di Taman Nasional Kerinci Seblat. Masyarakat Kerinci mengolah Kantung Semar menjadi Lemang Kantong Semar atau biasa disebut dengan kancung beruk. Air Sebuk Kawo ini terbuat dari tunas muda pohon kopi yang dikeringkan. Setelah kering, daun tunas muda pohon kopi kemudian diremas dan diseduh 
dengan air panas. Air seduhan tunas muda pohon kopi ini kemudian diminum. Biasanya, air kawo disajikan dalam tempurung kelapa.StrukturAnalytical Hierarchy Process(AHP) hasil dari perhitungan vertikal dengan bobot dan kriteria adalah

\section{Gambar 2}

Hasil Perhitungan Vertikal Struktur Hirarki Strategi Potensi Bauran Pemasaran Pengembangan Wisata Kuliner

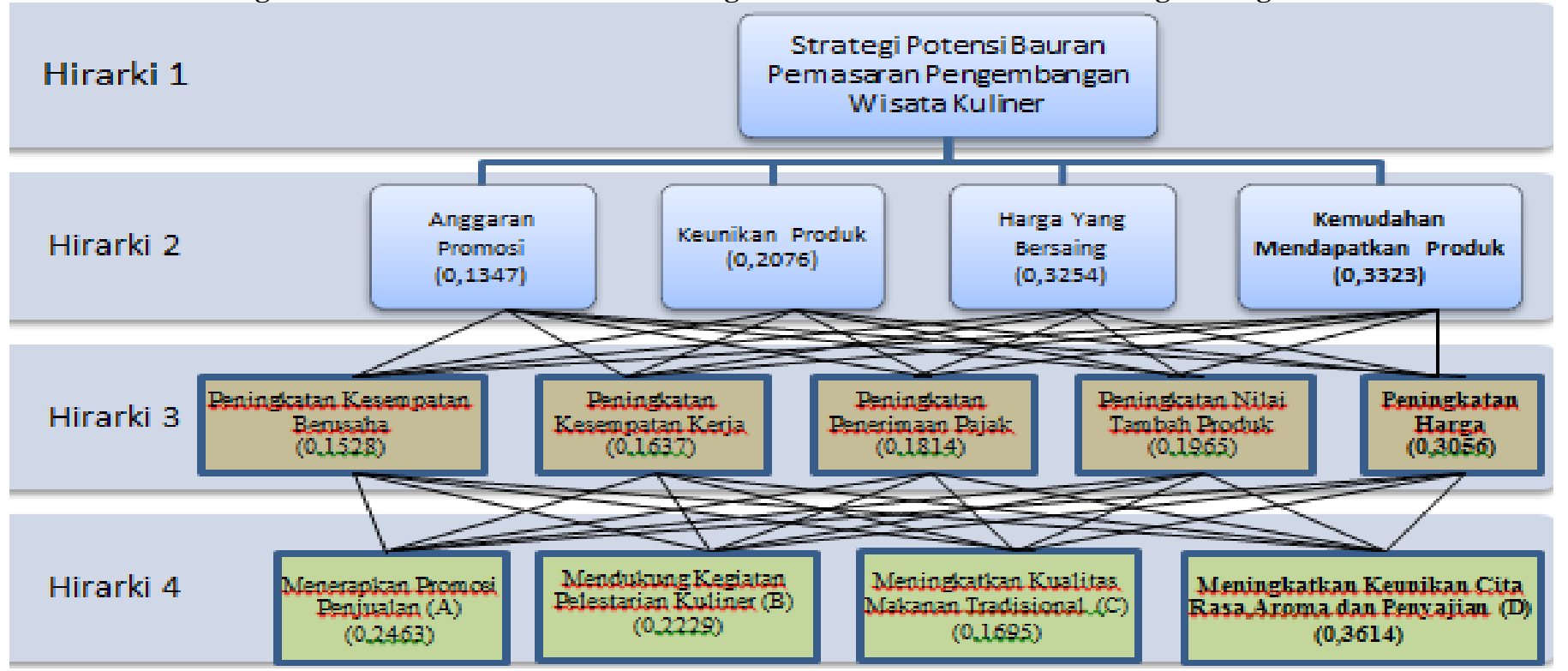

\section{SIMPULAN}

1. Terdapat empat faktor yang diidentifikasi sebagai faktor penyusunanbauran pemasaran pengembangan wisata kulineryaitu :Kemudahan Mendapatkan Produk, harga yang bersaing, keunikan produk dan anggaran promosi. Unsur faktor Kemudahan Mendapatkan Produk menjadi prioritas yang paling berpengaruh dengan nilai bobot $(0,3323)$.

2. Terdapat lima tujuan yang diidentifikasi sebagai tujuan dalam strategi potensi pengembangan wisata kuliner adalah Peningkatan Harga, Peningkatan Nilai Tambah Produk, Peningkatan Penerimaan Pajak, Peningkatan Kesempatan Kerja dan Peningkatan Kesempatan Berusaha. Unsur tujuan untuk Peningkatan Harga menjadi tujuan yang paling utama dengan nilai bobot $(0,3056)$.

3. Terdapat empat alternative yang diidentifikasi sebagai alternative yang bisa digunakan dalam strategi pengembangan wisata kulineryaitu :Meningkatkan Keunikan Cita Rasa, Aroma dan Penyajian, Menerapkan Promosi Penjualan, Mendukung Kegiatan Pelestarian Kuliner dan Meningkatkan Kualitas Makanan Tradisional. Meningkatkan Keunikan Cita Rasa, Aroma dan Penyajian dari produk produk wisata kuliner menjadi alternative strategi terbaik dari pengembangan strategi wisata kuliner di Kabupaten Kerinci dengan nilai bobot (0,3614).

\section{DAFTAR PUSTAKA}

Okech, Roselyne N. 2014. Developing Culinary Tourism: The Role of Food as a Cultural Heritage in Kenya. ISBN: 978-1-941505-14-4 Chennai, India 11-13 July 2014 Paper ID: CF412

Rahayu, Martha. 2014, Survei Hilton Worldwide, Menyingkap Budaya Wisata Kuliner di Asia Pasifik.

Ansofino. 2012. Potensi Daya Tarik Obyek Pariwisata Dalam Pembangunan Ekonomi Sumatera Barat. Economica, Jurnal Program studi Pendidikan Ekonomi STIKIP PGRI Sumbar Vol.1No.1

Besra, Eri. 2012. Potensi Wisata Kuliner Dalam Mendukung Pariwisata Di Kota Padang. Jurnal Riset Akuntansi Dan Bisnis Vol 12 No . 1 / Maret2012

Renko, S Renko, N \& Polonijo, T. 2010. Understanding the role of food in rural tourism development in a recovering economy“, Journal of Food Products Marketing, vol. 16, no. 3, pp. 309-324. 
Dougherty, ML, Brown, LE \& Green, GP 2013, The social architecture of local food tourism: Challenges and opportunities for community economic development‘, Journal of Rural Social Sciences, vol. 28, no. 2, pp.1-27.

Kim, YG, Eves, A \& Scarles, C 2009,_Building a model of local food consumption on trips and holidays: A grounded theory approach', International Journal of Hospitality Management, vol. 28, no. 3, pp.42331.

Bowen, S .2010. Embedding local places in global spaces: Geographical indications as a territorial development strategy', Rural Sociology, vol. 75, no. 2, pp.209-43.

Prayogi, Dian. 2017. Pengembangan Potensi Wisata Kuliner Kota Malang Berbasis Sumber Daya Lokal. ISSN (print) : 1410 - 7252 ISSN (electronic): 2541 - 5859 Vol. 2 No. 01 Juni 2017

Rismiyanto, Edy. 2015. Jurnal MAKSIPRENEUR, Vol. V, No. 1, Desember 2015, hal. 46 - 64. Fakultas Ekonomi Universitas Proklamasi 45Yogyakarta

Torres, R 2002,_Toward a better understanding of tourism and agriculture linkages in the Yucatan: Tourist food consumption and preferences', Tourism Geographies, vol. 4, no. 3, pp. 282-306.

Richardson, Robert B. 2010, The Contribution Of Tourism to Economic Growith and Food Security. USAID Mali : Office of Economic Growth : Michigant StateUniversity.

Everett \& C. Aitchison . 2008. The Role of Food Tourism in Sustaining Regional Identity: A Case Study of Cornwall, South West England. Journal Of Sustainable Tourism Vol. 16, No. 2,2008 